\title{
O ANO INTERNACIONAL DA LUZ E A INOVAÇÃO
}

\author{
Ivo Leandro Dorileo \\ Engenheiro Eletricista, Doutor em Energia/UNICAMP \\ Coordenador do NIEPE - Núcleo Interdisciplinar de Estudos em \\ Planejamento Energético da Faculdade de Economia/UFMT
}

Certamente Albert Einstein e Max Planck, tutelares da física moderna, anteviram, no início do século XX, a evolução e as aplicações generalizadas das tecnologias associadas ao eletromagnetismo e à energia. $\mathrm{Na}$ perspectiva dos cientistas, que dominaram o conhecimento da natureza dual partícula-onda da luz e das características atômicas da matéria, é compreensível também que não pudessem precisar sobre toda a inovação que adviria de seus trabalhos e sobre as modificações culturais e a rapidez com que a sociedade humana dotaria suas atividades cotidianas de elementos exossomáticos que necessitam de busca incessante de energia para acioná-los e movimentá-los.

O objetivo de se celebrar a luz justifica-se também através da originalidade da invenção humana no plano da utilização da energia: a eletricidade, a microeletrônica, a lâmpada elétrica, os instrumentos e as máquinas. Embora muitas vezes asfixiantes, os estímulos sociais tem conduzido ao desenvolvimento de um maquinismo sempre dependente das fontes de energia e, para seu aperfeiçoamento, das pesquisas e das ações intensivas para inovação.

O lugar e o papel da energia na vida humana estão presentes no inter-relacionamento das esferas das atividades (produção), sociais e ecológicas (da biosfera) e constituem-se no grande desafio com o qual a humanidade se confronta hoje. A interdependência destas três esferas demanda, obrigatoriamente, permanente pesquisa que possa oferecer uma sólida avaliação do relacionamento das sociedades com a energia; uma visão que traga reflexão profunda sobre as atividades e o impacto das intervenções humanas, sobre a pressão no meio ambiente e todos os efeitos a propósito dos próprios ecossistemas que as sustentam.

Para o Brasil, o ano internacional da luz circunscreve, ainda, um conjunto de fatores e remete à reflexão e à verificação das mudanças tecnológicas em intervalos de tempo cada vez mais curtos, provocando solicitações drásticas da ciência, afetando diretamente a vida das pessoas ao requererem mudanças de hábitos, novos conhecimentos e novas habilidades, com especificidades diferenciadas. Conduz à reflexão da situação da ciência e tecnologia brasileiras diante de um mundo competitivo e se a sua pesquisa tem dado resposta com respeito a tecnologias inovadoras.

Expressei no meu livro "Eficiência Energética e Prospecção Tecnológica na Indústria Brasileira" (EdUFMT, 2013) que para um desenvolvimento pleno da pesquisa, desenvolvimento e inovação (P\&D\&I), o país deve quebrar muitos, senão todos os 
paradigmas, através da união e atuação coordenada dos atores fundamentais: Empresas, Governo e Universidade. Um dos paradigmas é o da barreira monetária, pois a liderança tecnológica é uma correlação direta entre potencial de mercado e capacidade de investimento. Produtos mais sofisticados, que incorporam maior índice de tecnologia, tem um custo mais elevado. Outro paradigma é o gargalo educacional, uma vez que existe a real necessidade de se robustecerem os recursos humanos para as Ciências e Engenharia, pois a formação de talentos é inerente ao processo de criação e inovação; e os contornos das atividades produtivas que tendem a ganhar mais peso no futuro deverão requerer mais mão de obra com este perfil.

O desafio consiste em preparar-se o quanto antes, pois os esforços do sistema educacional surtem efeito entre uma e duas décadas. As estatísticas mostram que economias como a asiática e a americana tem apresentado números crescentes de engenheiros e doutores, reforçando a sua capacitação técnica e produção. Este fato mostra para o Brasil o que deve ser feito para tornar-se uma potência no desenvolvimento de tecnologias inovadoras - aquelas que carregam conhecimento intensivo de caráter multitecnológico e que sinalizam para um desenvolvimento de tecnologias não intuitivas, levando para outro caminho diferente do que se trilha hoje no país. São padrões de inovação as Tecnologias da Informação e Comunicação (TICs), permeativas no sentido de que afetam e influenciam inúmeras outras técnicas. A biotecnologia, outra tecnologia inovadora, altamente dependente dos avanços obtidos em automação, processamento e comunicação, sendo impossível para ela decifrar o código genético sem as TICs.

Neste contexto, o aprimoramento tecnológico nacional, através da pesquisa e desenvolvimento, deve ser fomentado em maior monta, tanto estruturalmente, com instituições habilitadas em todo o território, quanto com receitas, de forma continuada, com fito na sobrevivência no longo prazo de todos os setores produtivos e na sua situação globalizada de competição tecnológica. Mas esta meta só será atingida em um sistema de inovação que compreenda um conjunto complexo de instituições e agentes econômicos e que mantenham relações orgânicas entre si, sustentados por política de investimento para geração de conhecimento e novas técnicas. Na década de 2000, em média, apenas 13,0\% da indústria brasileira incorporaram inovações em produtos e processos. O Brasil não pode continuar negligenciando o binômio investimento em pesquisa aplicada versus inovação. Ao proclamar 2015 o ano internacional da luz, a UNESCO acena para a humanidade atuar em várias dimensões da ciência, com potencial extraordinário de avanço, e, nas suas próprias palavras, "uma oportunidade única para se inspirar, para se educar e para se unir em escala mundial". 